\title{
TAVSHED OG VOLD MOD KVINDER
}

\author{
Erfaringer fra et projekt om vold mod kvinder i etniske minoritetsfamilier
}

\section{BO WAGNER SØRENSEN, YVONNE MØRCK OG SOFIE DANNESKIOLD-SAMS $\varnothing E$}

Denne artikel belyser tre former for tavshed, vi har mødt i forbindelse med forskningsprojektet „Vold mod kvinder i etniske minoritetsfamilier - en kvalitativ undersøgelse med fokus på fremadrettede indsatser", der er afsluttet med bogen Familien betyder alt. Vold mod kvinder i etniske minoritetsfamilier. ${ }^{1}$ Tavshed er af gode grunde en størrelse, der er vanskelig at forholde sig til endsige begribe, og det at tage udgangspunkt $i$ tavshed kan være en risikabel affære i akademiske kredse, fordi tavshed lægger op til uendeligt mange mulige fortolkninger. En artikel, der har tavshed som udgangspunkt, risikerer at blive karakteriseret som impressionistisk snarere end empirisk funderet, fordi tavshed repræsenterer en form for data, der rummer for mange betydninger. Vi vover alligevel forsøget, idet vi forankrer begrebet tavshed $\mathrm{i}$ en konkret social praksis med udgangspunkt $\mathrm{i}$ spørgsmål som: Hvad kan der tales og ikke tales om vedrørende vold mod kvinder og i særdeleshed vold mod etniske minoritetskvinder, på hvilken måde og af hvem? Samtidig ser vi tavshed som en fortløbende proces snarere end et endegyldigt, entydigt produkt eller resultat af forudgående processer. Det betyder, at vi har fokus på, hvordan tavsheder opretholdes ved hjælp af fortielse, og hvordan forsøg på at bryde samme tavsheder mødes med forsøg på tavsliggørelse.

Den første form for tavshed, ${ }^{2}$ vi mødte, handler om forsøg på at fortie problemet vold mod kvinder internt i de etniske minoritetsfamilier og -miljøer. Denne tavshed fik vi indblik i, da vi foretog interviews med 42 voldsramte kvinder og et større antal krisecentre i forbindelse med projektet. Den anden form for tavshed, vi oplevede, handler om forskeres forsøg på fortielse af problemet vold mod kvinder i etniske minoritetsfamilier. Flere reaktioner på vores forskningsprojekt - selv da det kun forelå som titel og var i sin vorden - var, at der var tale om et emne, man enten helt burde holde sig fra, eller som man skulle behandle med allerstørste varsomhed. Vi er blevet mødt af bekymrede miner, sigende tavshed og mere åbenlys kritik fra en række forskere, mænd som kvinder, herunder køns- 
forskere. Den tredje form for tavshed, vi mødte, handler om en aktuel tendens til tavsliggørelse af visse aspekter og perspektiver på volden. Vi tænker her på henholdsvis seksuel vold og på koblingen mellem køn, magt og vold.

Vi vil indlede med en kort beskrivelse af det forskningsprojekt og materiale, som artiklen tager afsæt i. Derefter vil vi vise, hvordan vold mod kvinder (og børn) eller ,vold i hjemmet“ er blevet associeret med tavshed i såvel den forskningsbaserede som mere populære litteratur siden 1970, hvor denne form for vold begyndte at blive omtalt som et samfundsmæssigt problem. Det giver os anledning til at se nærmere på begrebet tavshed med henblik på at præcisere vores brug af det $i$ artiklen. Vi vender efterfølgende tilbage til de omtalte tre tavsheder, som vi vil beskrive hver for sig med inddragelse af empirisk materiale. Endelig vil vi i konklusionen sammenholde de tre tavsheder og vise, hvordan de er forbundet.

\section{Forskningsprojektet og materialet til artiklen}

Forskningsprojektet blev udbudt offentligt i efteråret 2008 af TrygFonden og Danner, som i de fleste danskeres bevidsthed er indbegrebet af et dansk kvindekrisecenter. Baggrunden var Danners mangeårige erfaring med en overrepræsentation af kvinder med etnisk minoritetsbaggrund blandt husets brugere, en erfaring, som Danner delte med størstedelen af landets knap 40 krisecentre organiseret under LOKK, Landsorganisation af Kvindekrisecentre. Med projektet ønskede udbyderne en analyse af karakteren af den vold, der udøves mod kvinder i etniske minoritetsfamilier, samt en kortlægning af eksisterende tilbud for målgruppen med henblik på forebyggelse af volden og forslag til indsatser. Formålet var med andre ord dels at få indblik i volden via kvinderne selv, dels at få indblik i, hvad krisecentrene kunne tilbyde kvinderne, og om disse tilbud var tilstrækkelige. Det var endvidere specificeret, at undersøgelsen skulle være baseret på 40 interviews med kvinder, der enten havde været eller aktuelt var på krisecenter, og at kvinderne skulle tilhøre målgruppen: etniske minoritetsfamilier. ${ }^{3}$

At projektets fokus var på etniske minoritetsfamilier, skyldtes fra Danners side en erfaringsbaseret forventning om, at karakteren af volden kunne være anderledes end den vold, etnisk danske kvinder typisk udsættes for, ${ }^{4}$ og en antagelse om, at vold i etniske minoritetsfamilier var underbelyst og uudforsket i modsætning til vold mod kvinder i etnisk danske familier. Vi endte med at bekræfte den omtalte forventning, idet vi konkluderede, at kvinder i etniske minoritetsfamilier ofte udsættes for vold fra mere end en voldsudøver, idet volden ofte er æresbaseret (Danneskiold-Samsøe, Mørck \& Sørensen 2011). Antagelsen om, at volden i etniske minoritetsfamilier er forskningsmæssigt underbelyst i Danmark, viste sig også at være korrekt. ${ }^{5}$ LOKK har ganske vist tidligere taget initiativ til 
forskning om vold mod kvinder med udenlandsk baggrund, men målgruppen har i den forbindelse været etnisk danske mænd gift eller samlevende med kvinder født uden for Danmark (LOKK 2003; Nielsen \& Gitz-Johansen 2006).

Vores materiale til projektet består af interviews med 42 kvinder, der alle på nær én har været på krisecenter på grund af vold. ${ }^{6}$ De fleste af disse kvinder, 30 , har rødder i mellemøstlige lande som Tyrkiet, Irak og Pakistan, ${ }^{7}$ mens kvinder fra Østeuropa, Vestafrika og Sydasien udgør andre, mindre kategorier. Kvinderne definerer sig selv som etniske andre i forhold til den danske majoritetsbefolkning. Endvidere indgår to etnisk danske kvinder, der har været gift med mænd med etnisk minoritetsbaggrund. Nogle af kvinderne er født i Danmark, mens andre er kommet til landet $\mathrm{i}$ en ung alder eller som voksne. Femten af kvinderne er således kommet som ægteskabsmigranter.

I denne artikel, hvor vi har fokus på tre former for tavshed, henviser vi i forbindelse med den første form for tavshed primært til interviewmaterialet med kvinder med mellemøstlige og sydasiatiske rødder, idet der tegner sig et fælles mønster af fortielse af volden i de familier og miljøer, de kommer fra. Afsnittet henviser også til projektets interviews med krisecentermedarbejdere. Den anden form for tavshed illustreres ved hjælp af erfaringsbaseret materiale af mere flygtig karakter, idet vi gør brug af mundtlige udtalelser og reaktioner fra forskere, vi har mødt i forskellige sammenhænge. Siden er der kommet noget på tryk en positiv anmeldelse (Ouis 2012a) og en kritik af vores arbejde (Andresen \& Andreassen 2012) - der kan bekræfte vores tidlige erfaringer. Den tredje form for tavshed tager udgangspunkt i skriftligt materiale $\mathrm{i}$ form af regeringens handlingsplaner og et offentligt debatoplæg om vold i nære relationer.

\section{Koblingen mellem tavshed og vold mod kvinder}

Vold mod kvinder og børn, som også undertiden kaldes ,,vold i hjemmet“ eller „,vold i familien“, 8 har været koblet til begrebet tavshed siden de tidlige 1970'ere, hvor kvindebevægelsen pegede på problemet og indledte arbejdet med at få volden anerkendt som et samfundsmæssigt problem. Det første krisecenter for voldsramte kvinder åbnede i England i 1971, og den første hotline for voldtægtsofre blev etableret i USA i 1972 (Kelly 1988:1). I Danmark oprettedes det første krisecenter, Ringsted Krisecenter, i 1978, mens Danner åbnede året efter i 1979. ${ }^{9}$ Kvindebevægelsens strategi handlede om at gøre det private offentligt ved netop at bryde tavsheden med sloganet: Stop volden, bryd tavsheden. Bogen Vold ties ikke ihjel, som udkom i 1984 og er skrevet af den danske psykolog og krisecenteraktivist Else Christensen, peger tilsvarende på koblingen mellem tavshed og vold og ikke mindst forsøget på at bryde denne tavshed. Tidligere var vold, 
der fandt sted i familien, omgærdet af forestillinger om, at familien er privat, og hvad der fandt sted dér, unddrog sig i vid udstrækning samfundsmæssig indblanding. Volden blev opfattet som et privat problem, ikke en strafbar handling. Selv om der er sket et vist skred i denne opfattelse over tid, hænger forståelsen af volden som privat problem stadig ved (se fx Balvig \& Kyvsgaard 2006; Harne \& Redford 2010:20).

Grundlæggeren af det første krisecenter i England, Erin Pizzey, udgav i 1974 bogen Scream Quietly or the Neighbours Will Hear, der fik stor udbredelse og blev oversat til flere sprog, herunder til dansk i $1979 .{ }^{10}$ Titlen var ikke en opfordring, men netop en konstatering af, hvordan volden blev holdt inden for hjemmets fire vægge, fordi både voldsudøver og voldsoffer var af den opfattelse, at det ikke kom andre ved, selv om de kunne tænkes at have forskellige grunde til at gå stille med det. Historisk set har kvinder holdt sig tilbage af frygt for, hvordan manden vil reagere, såfremt volden afsløres.

Kvinder har også holdt sig tilbage af frygten for „victim blaming“ (Dobash \& Dobash 1998:152). Dette udbredte fænomen betyder, at voldsofre populært antages selv at have lagt op til at blive udsat for vold, og at de dermed også antages at være medansvarlige for volden. Frygten er ikke ubegrundet. Den psykiatriske og individpsykologiske forskning i vold i familien har løbende peget på, at kvinder, der udsættes for vold i ægteskabet eller parforholdet, har en ganske særlig psykologisk profil (for en kritik, se Dobash \& Dobash 1992; Lundgren 1990:14; 2004:79f.).

At det ikke er uproblematisk at bryde tavsheden, fremgår af to nyere publikationer, der rummer personlige historier. I introduktionen til Lyckliga slut. Sjutton berättelser om vardagsvåldet skriver forfatteren og redaktøren af antologien Susanna Alakoski, ${ }^{11}$ at hun i forbindelse med bogen spurgte hundredvis af svenske kvinder, om de ville bidrage med deres historie. Og hun skriver videre, at stort set alle svarede, at de havde noget at fortælle, men at de ikke turde eller kunne. Af hensyn til manden, af hensyn til børnene, til familien, kollegerne - og måske af hensyn til sig selv? For venner og slægtninge fraråder kvinder at fortælle, for hvad vil der ske, hvis man gør det? (Alakoski 2007:7). Som bogen viser, findes der imidlertid kvinder, som ikke (længere) vil tie.

Det gælder også den danske forfatter og oversætter Ilse M. Haugaard, som i 2011 udgav erindringsbogen Fanden og hans pumpestok. Et mysterium, hvor hun beretter om seks års ægteskab med en voldelig mand. Begge var omkring 50 år og havde voksne børn fra tidligere forhold. Hun var en udadvendt person med en stor omgangskreds. Alligevel lykkedes det for hende at skjule volden for omverdenen. Hun skammede sig over, at hun ,fandt sig $i^{\prime \prime}$ at være et voldsoffer. Da hun endelig forlod manden og også begyndte at fortælle om volden, blev hun 
imidlertid overrasket. Skønt de fleste mennesker reagerede med afstandtagen til den voldelige mand, var der dem, ,der mente, at jeg sikkert overdrev, og at jeg ikke kunne være bekendt - over for ham - at gå og fortælle den slags, at det var noget, der tilhørte privatlivet. Den holdning var det sært nok mest kvinder, der gav udtryk for, selv om jeg er temmelig sikker på, at lige så mange mænd tcenkte det samme" (Haugaard 2011:203). Alligevel besluttede hun sig for at skrive en bog om volden. Det var nemlig gået op for hende, ,at vores uudtalte sociale sammensværgelse om at beskytte bødlerne i egen midte efterhånden har frataget det enkelte individ ansvaret for dets handlinger. Ved at fortie forbrydelsen legitimerer vi bødlen og hans vold, og det er lige før, der er lige så megen sympati med ham som med hans ofre“" (op.cit.204). I forbindelse med et interview opfordrer Haugaard andre voldsramte kvinder til at fortælle om volden, for: „Man kommer aldrig væk fra skyld og skam, hvis man ikke taler om det. Voldsmanden siger: 'Det er din egen skyld, at jeg slår dig.' Men sådan hænger tingene ikke sammen“ (Remar 2011).

\section{Tavshed, fortielse og tavsliggørelse}

Antropologen og lingvisten Susan Gal skriver i sin oversigtsartikel „Between Speech and Silence“ fra 1991, at tavshed har været et centralt tema inden for den feministiske forskning, og at tavshed i disse arbejder typisk er blevet opfattet som et resultat af og et symbol på passivitet og afmagt (Gal 1991:175). Den underliggende idé er, at personer eller grupper, der ikke kan komme til orde, heller ikke kan gøre deres erfaringer gældende, og at de af samme grund ikke har indflydelse på deres eget liv. Ifølge Gal er forbindelsen mellem køn, tale og magt imidlertid mere kompleks, og tavshed er ikke altid udtryk for afmagt, idet tavshed kan bruges om magtmiddel og som strategisk forsvar. Gals interesse ligger i at afdække den omtalte forbindelse mellem køn, tale og magt og se, hvordan den kommer til udtryk i konkrete empiriske studier.

Som Gal nævner, er det antropologens opgave at finde ud af, under hvilke omstændigheder kvinder - og for den sags skyld informanter i bred forstand kan tale, og hun fremhæver genrer skabt af kvinder selv med henblik på at reflektere over egne erfaringer som særlig betydningsfulde, fordi de ikke primært er et produkt af det etnografiske interview (op.cit.191f.). Hvis vi tænker vores eget projekt ind, kan det siges, at der er tale om et sammenfald mellem det etnografiske interview og en allerede eksisterende genre, som er udviklet af kvindebevægelsen og fortsat praktiseres på krisecentrene, nemlig at gøre det private offentligt ved at fortælle sin voldshistorie. Således brydes den tavshed om vold mod kvinder, der typisk råder. Den feministisk orienterede voldsforskning har det $\mathrm{i}$ 
øvigt som sin strategi at gøre kvinders private smerte og skam offentlig kendt, idet det antages, at tavshed tjener voldsudøvere snarere end voldsofre (Kelly et al. 1996; McKie 2005).

Tavshed kan henvise til en tilstand, men vi finder det mere interessant at anskue tavshed som en proces, idet tavshed typisk hverken er entydig eller permanent, men noget, nogen forsøger at bryde eller opretholde på forskellig vis. På engelsk anvendes begrebet ,silence“ da også aktivt i form af ,silencing“, hvilket på dansk både betyder at fortie og at gøre tavs eller lukke munden på. At fortie vil sige at undlade at fortælle, mens det at (forsøge at) gøre tavs er en handling, der retter sig mod andre.

Ifølge Liz Kelly, der er sociolog og professor i seksualiseret vold, har tavshed og fortielse hindret kvinder og børn i at tale om deres voldserfaringer og dermed også hindret dem i at søge støtte og kræve retfærdighed (Kelly et al. 1996). På konferencen „The Silencing of Violence Against Women“ i 2011, ${ }^{12}$ hvor Kelly var en af hovedtalerne, var hun imidlertid inde på, at „silencing“ typisk bliver og er blevet anvendt meget bredt og diffust inden for feltet vold mod kvinder, og at det derfor undertiden bliver misvisende. I sit oplæg rettede Kelly en kritik mod en forenklet forståelse og anvendelse af „silencing“ af den simple grund, at langt flere kvinder taler offentligt om vold end nogensinde før, og at det sker i rigtig mange lande. Til gengæld er nogle former for vold fortsat nemmere at tale om - „more speakable“ - end andre. I de europæiske lande generelt er der således en modvilje mod at beskæftige sig med seksuel vold, mens der viser sig en ganske anden interesse for ,partnervold“. ${ }^{13}$ Kelly var videre inde på, at der er sket et (uheldigt) skift i retning af en kønsneutral voldsforståelse med fokus på risikofaktorer og subkulturer, og at feministiske perspektiver på vold, som har vist forbindelsen mellem de forskellige former for vold mod kvinder og koblet dem til intersektionelle magtsystemer, er blevet tilsidesat til fordel for juridiske og medicinske diskurser. Så selv om flere kvinder end nogensinde før står frem og taler om volden, var Kelly inde på, at disse kvinders stemmer bliver hørt og forstået på en ganske anden måde end tidligere, hvilket fik hende til at stille spørgsmålet, om det er kvinder eller snarere feministiske perspektiver på volden, der gøres tavse. Tavshed, fortielse og tavsliggørelse indgår således i en fortløbende social proces.

\section{Tavshed i de etniske minoritetsmiljøer}

I det følgende anvendes resultater fra vores bog til at sætte fokus på tavshed og fortielse (Danneskiold-Samsøe, Mørck \& Sørensen 2011). Fremstillingen er således en overordnet analytisk beskrivelse af de tavsheder og fortielser om 
vold mod kvinder i etniske minoritetsfamilier, som vores materiale indeholder. Vi har kun mulighed for at præsentere nogle få eksempler og henviser til bogen for mere deltaljerede og individualiserede beskrivelser af kvindernes tavshedsog fortielseserfaringer samt de erfaringer, som krisecenterpersonalet og andre aktører har hermed.

Vores undersøgelse har vist en stor modstand i etniske minoritetsmiljøer mod at tale om ,vold i familien“ og vold mod kvinder. ${ }^{14}$ Det fremgår med al tydelighed af vores interviews med kvinderne, at de ikke har kunnet give udtryk for deres voldserfaringer, mens de levede i miljøet. Kvinderne har imidlertid også vanskeligt ved at trænge igennem med deres voldserfaringer, efter at de er kommet ud af volden. Deres væsentligste motivation for at tale med os har således været at bidrage til at gøre noget ved problemet. De håber nemlig, det kan gavne andre kvinder, at de baner vejen ved at sætte ord på volden og gøre den offentlig. Ingen af de kvinder, vi har talt med, har udtrykt bekymring for billedet eller mediebilledet af voldelige mænd med etnisk minoritetsbaggrund, hvilket, som det vil fremgå senere, fremstår som centralt for nogle forskeres tilgang til vold mod etniske minoritetskvinder. Kvinderne ønsker grundlæggende blot at kræve deres ret og få mulighed for at skabe sig et liv uden vold.

Det er vores indtryk, at kvinder, der har valgt at tale om volden i stedet for at fortie den, herunder også nogle af dem, der indgår i vores undersøgelse, har en vigtig rolle at spille som forandringsaktører internt i etniske minoritetsmiljøer. ${ }^{15}$ Endvidere kan kvinders brud på tavsheden sandsynligvis bidrage til at styrke deres seksuelle medborgerskab, dvs. råderetten over deres egen krop, følelser og seksuelle relationer og dermed over valg af relationer, erfaringer og identitet (Plummer i Weeks 1999:37; se også Danneskiold-Samsøe, Mørck \& Sørensen 2011:165).

Undersøgelsen viser, at de interviewede kvinder udsættes for både et ydre og et indre pres. De er opvokset i en patriarkalsk, kollektivt orienteret familieform, der bl.a. indebærer, at loyalitet med den udvidede familie typisk sættes højere end det enkelte medlems egne ønsker og behov. Kvinderne har, hvilket er typisk for alle mennesker, i vid udstrækning internaliseret de værdier og familie- og ægteskabspraksisser, som de er opvokset med. Dette indebærer fx en mere eller mindre udtalt forventning om, at de, når den tid kommer, indgår et arrangeret ægteskab. Flertallet af de interviewede gifte eller fraskilte kvinder med mellemøstlige og tamilske rødder har da også indgået et arrangeret ægteskab og ofte i en ung alder. Oftest har de, og i flere tilfælde også deres forældre, haft meget lidt kendskab til manden før ægteskabet. De har været meget unge (gennemsnitlig 20 år), de har typisk ikke været i gang med en uddannelse, og de har (haft) et spinkelt netværk, hvilket har bevirket, at de har været lette at kue og 
true til tavshed. Det gør sig især gældende for ægteskabsmigranterne, der kom til et nyt land, hvor de ikke kendte sproget eller samfundet, og hvor deres nærmeste familie var langt væk.

Kvinderne udsættes for et stort konformitetspres fra både egen familie og (eventuel) svigerfamilie og fra, hvad vi kalder baglandet. Kvindens bagland, dvs. hendes familie og slægt på tværs af nationale grænser samt det etniske minoritetsmiljø i Danmark og i andre diasporamiljøer, har indflydelse på hendes liv, herunder om hun kan komme til orde om den vold, hun udsættes for. Både de unge kvinder, der er opvokset i Danmark, og kvinder, der er kommet til landet som ægteskabsmigranter, er således udsat for transnational social kontrol (Timmerman 2006). Hvordan en families piger og kvinder opfører sig, har nemlig betydning for hele familiens og slægtens omdømme. En ung kvinde med arabiske rødder siger fx, at hendes slægt på morens side er kendt i oprindelseslandet for at være en ,god familie“, idet ,ingen snakker om deres døtre“.

Sladder gør, at voldsramte etniske minoritetskvinder har svært ved at stole på og være solidariske over for hinanden. Susan Gal peger på, at kvinders respons på eller strategier til bekæmpelse af deres magtesløshed kan resultere i, at den reproduceres. Som eksempel bruger hun en etnografisk undersøgelse af en spansk landsby, hvor kvinders mest magtfulde verbale redskab til at opnå social kontrol er sladder. Magtmidlet sladder er imidlertid tveægget. For skønt sladder kan bidrage til at undergrave mandlig autoritet, udgør denne negative magtform også en fælde for kvinderne selv. For det at være under konstant verbalt opsyn begrænser kvinders adfærd og bidrager til at holde dem på (rette) plads (Gal 1991:183f.). Ifølge såvel de interviewede kvinder som krisecenterpersonalet anvendes sladder da også som et meget effektivt redskab til social kontrol, hvilket svækker kvinders netværksdannelse, mens de udsættes for vold, og efter at de har forladt et voldeligt hjem eller ægteskab. Når voldsramte kvinder tager sladder alvorligt, hænger det sammen med, at ikke blot deres eget, men også deres slægts omdømme står på spil, hvis de offentliggør den vold, de udsættes for enten i barndomshjemmet og/eller i et ægteskab eller kæresteforhold. Familiens status og ære beror i høj grad på familiens kvinder og deres adfærd, især hvordan de forvalter deres kroppe og seksualitet. Den rådende holdning, som kvinderne er socialiseret til og i vid udstrækning også tilslutter sig, er, at seksuelle relationer udelukkende bør foregå inden for ægteskabets rammer.

Det er derfor ikke overraskende, at såvel kvinderne som krisecenterpersonalet (og andre aktører) giver udtryk for, at der blandt etniske minoriteter og i baglandet som helhed er et udbredt syn på krisecentre som samlingssteder for ,dårlige“" kvinder, dvs. kvinder, der svigter familien og kun tænker på sig selv. Dette er et syn, som mange kvinder i miljøet deler, fordi de er vokset op med det, samtidig med at krisecentre fremstilles i et meget negativt lys, nærmest som udklæk- 
ningssteder for illoyale, faldne og oprørske kvinder. Najah, der er ægteskabsmigrant fra Irak, fortalte fx, at hendes mand på en måde ,havde hjernevasket mig. Han fortalte mig, at der kun kommer dårlige mennesker på krisecentre. Det er ligesom et fængsel. Det var det billede, jeg havde. Det var for at lukke alle døre for mig, for at jeg ikke skulle løbe hjemmefra. [...] Der [på krisecentre] kommer kun alkoholikere og ludere, og dine børn bliver taget fra dig, og du får ikke mad. Du bliver spærret inde, og du kommer aldrig ud igen. Han truede mig med alt“ (Danneskiold-Samsøe, Mørck \& Sørensen 2011:175, se også 174ff.). Undersøgelsen viser, at kvindernes erfaring er, at information om krisecentre forties og/eller fordrejes og anvendes som skræmmebilleder for at fastholde dem i det voldelige forhold.

Vores analyse viser endvidere, at kvinderne har en udbredt loyalitetsfølelse over for deres familie, hvilket typisk gør det vældig vanskeligt for kvinderne at bryde tavsheden omkring volden (selv når den har været meget voldsom og langvarig) og at henvende sig til fx enkeltpersoner eller myndigheder uden for familien og slægten for at få hjælp til at forandre deres livssituation. For ægteskabsmigranter er der endvidere den barriere, at ægtemanden og svigerfamilien kan true dem med, at de bliver udvist af landet, hvis de beretter om volden. Kvinder kan også være bange for, at de mister retten til deres børn, og/eller at volden vil blive forstærket, hvis de bryder med voldsudøveren. Alle disse former for tavsliggørelse af voldsramte kvinder findes i interviewmaterialet, og en enkelt kvinde er blevet udvist, så man kan konstatere, at kvinderne har grund til at være bange for disse magtmidler. De kvinder, der indgår i vores undersøgelse, har imidlertid været modige og brudt tavsheden.

Nogle har også fortalt om volden, mens den stod på. De få kvinder i vores materiale, der har forsøgt at få familiemedlemmer eller andre i det etniske minoritetsmiljø i tale om volden, har dog sjældent mødt forståelse, men typisk tavshed eller ligefrem modstand og stigmatisering. Kvinder, der har betroet sig til familiemedlemmer eller signaleret til medlemmer i det etniske minoritetsmiljø, at de udsættes for vold, fx ved at fremvise blå mærker, er ikke blevet taget alvorligt. En ung kvinde, hvis onkel forgreb sig seksuelt på hende over længere tid, blev udsat for „victim blaming“, idet hendes far mente, at hun selv havde lagt op til det, og kaldte hende luder. Da den unge kvinde meldte onklen til politiet, blev sagen frafaldet på grund af mangel på bevis, idet alle familiemedlemmer vidnede til fordel for manden/onklen.

Nogle af de interviewede kvinder har (også) fortalt om volden til udenforstående, og nogle fik hjælp, andre gjorde ikke. Vi har flere eksempler på, at kvinderne har fået hjælp og støtte til fx at komme på krisecenter, hvis og når de har betroet sig om volden til en etnisk dansk arbejdskollega. Der er dog undtagelser, idet en ung kvinde har fortalt, at hun kontaktede to af sine skolelærere 
for at få hjælp, da hun som 14-årig blev udsat for et tvangsægteskab, og at lærerne ganske vist kom hjem til familien, men at det endte med, at moren inviterede dem med til bryllupsfesten, som de deltog i uden at hjælpe den unge kvinde. Hun måtte vente, til hun blev 18 år, før hendes voldshistorie blev taget alvorligt og hørt af repræsentanter fra det offentlige system. Hun vidste nemlig, at hun kunne tage på et krisecenter, når hun blev myndig.

Nogle kvinder fortier imidlertid den vold, de udsættes for. Der kan være flere grunde til, at kvinderne ikke beretter om volden til deres familie i oprindelseslandet eller andre steder. Familierne befinder sig langt væk, og kvinderne involverer typisk ikke familien i deres problemer, idet de ønsker at skåne dem, da de vurderer, at familien alligevel ikke kan stille noget op. Desuden er kvinderne heller ikke glade for at tale med familien og især ikke forældrene om skilsmisse. For hvad vil folk i forældrenes hjem(lands)by sige, hvis det rygtes, at hun tænker på eller ligefrem har forladt sin mand? Andre ægteskabsmigranter har simpelthen ikke haft mulighed for at fortælle, hvad de udsættes for, fordi de har været spærret inde i hjemmet og/eller kun har haft adgang til at tale i telefon med deres forældre, mens samtalen blev overhørt af ægtemand og/eller svigerforældre. Det gælder fx en af de unge interviewede ægteskabsmigranter, som var indespærret under sådanne omstændigheder i fem år.

Mange af kvinderne har dog været varsomme med at fortælle om volden til folk uden for familien og det etniske minoritetsmiljø. Både unge kvinder og voksne kvinder med børn har givet udtryk for, at de har været bange for, at volden ville fortsætte og måske endda blive forstærket, hvis de fortalte om den til fx lærere eller sagsbehandlere. Som den pige, hvis lærere blev indbudt og deltog i bryllupsfesten, da hun søgte om hjælp hos dem for at undgå tvangsægteskab, oplever unge og voksne kvinder, at myndighedspersoners indsatser kan være halvhjertede og misforståede. Samtidig frygter kvinderne for den efterfølgende straf, når og hvis familien finder ud af, at de har fortalt om volden og har søgt hjælp hos udenforstående såsom sagsbehandlere, socialrådgivere eller studievejledere.

Kvindernes beretninger viser, at der er flere perspektiver på vold mod kvinder. De kvinder, vi har talt med, er ikke i tvivl om, at volden er et problem, som ikke skal forties eller gemmes væk i privatsfæren, som voldsudøverne forsøger. Vi kan også konkludere, at der er flere former for tavshed på spil i forbindelse med vold mod kvinder i etniske minoritetsfamilier, der tilsammen udgør en massiv mur, som kvinderne skal overstige for at komme til orde om deres livssituation. Tavshed om volden er således en fortløbende proces, hvor tavsheder opretholdes ved hjælp af fortielse, og hvor forsøg på at bryde tavsheder bliver mødt med forskellige tavsliggørelsesstrategier. Skønt det typisk har været mænd, der har været voldsudøvere, er der også eksempler i vores undersøgelse på kvindelige volds- 
udøvere, ligesom repræsentanter af begge køn har bidraget til tavshed og fortielse af volden. Det er imidlertid ikke kun i etniske minoritetsmiljøer og deres transnationale netværk, at der råder en tavshed om vold mod disse kvinder. Den har vi også mødt blandt forskere.

\section{Forskeres opfordring til tavshed}

Siden vi startede på vores projekt om vold mod kvinder i etniske minoritetsfamilier, har vi mødt mange bekymrede miner, som vi her vil bruge som samlebetegnelse for folks reaktioner, der rummer både forbehold, forsigtighed, bekymring og åbenlys forargelse. Og forskere fremstår som de mest bekymrede, især dem, der beskæftiger sig med etniske minoriteter i Danmark i en eller anden forstand.

Allerede inden projektets start spurgte en bekymret forsker: „Hvordan vil I overhovedet gribe det an?" Forinden havde vedkommende givet udtryk for, at det var et projekt, der var uhyre vanskeligt at forholde sig til. Og vi svarede noget i stil med: „Som man plejer med interviewbaserede projekter: snakke med folk - her kvinderne - og høre, hvad de har at fortælle.“

„Godt det ikke er mig, der skal lave det", var der én, der sagde, og reaktionen skyldtes, at projektet indskrev sig i et politisk minefelt, hvor man måtte bevæge sig med største forsigtighed. En anden forsker gav udtryk for, at kvinderne, vi talte med, sandsynligvis fordrejede sandheden ved at fortælle os de historier, som de antog, at vi ønskede at høre, nemlig historier om undertrykte indvandrerkvinder, som ifølge samme forsker passer ind i den herskende danske diskurs om de andre. „Er I ikke bange for, at I kommer til at dæmonisere indvandrermænd?“ er vi også blevet spurgt. Og så er vi af flere forskere blevet kraftigt opfordret til at inddrage migrationskonteksten i vores arbejde, men det har sjældent været klart, hvad der mentes med det (om forklaringer og bortforklaringer på vold, se Danneskiold-Samsøe, Mørck \& Sørensen 2011:28ff.; 104ff.).

En del forskeres umiddelbare reaktion på vores projekts fokus på vold mod kvinder var at efterlyse undersøgelser af kvinders vold mod mænd ud fra den betragtning, at her er tale om et tabubelagt emne og et overset problem. Andre har spurgt, hvorfor vi ikke har snakket med kvindernes mænd, for det kunne være rigtig interessant, dvs. mere interessant. ${ }^{16}$ Undervejs har vi også fået indtryk af, at en del forskere synes, at de har hørt nok om kvindelige voldsofre eller kvindelige ofre i det hele taget. Når der så oven i købet er tale om fokus på etniske andre, bidrager man - dvs. vi i dette tilfælde - til at eksternalisere volden, dvs. andetgøre eller eksotisere den.

Når vi vælger at inddrage ovenstående udtalelser og reaktioner, som vi er stødt på undervejs i arbejdet med forskningsprojektet, skyldes det, at de vid- 
ner om en berøringsangst, som vi finder det væsentligt at pege på. En nylig kritik af vores bog opsamler de fleste af de nævnte punkter, idet de to kritikere mener, at bogen ,(måske mod forfatternes gode viljer?) bidrager til at cementere de generaliserende eksisterende (myte)fortællinger om minoritetskvinder som ofre for vold“ (Andresen \& Andreassen 2011).${ }^{17}$ De siger i samme forbindelse, at den forskning, som bogen repræsenterer, kan gøre mere skade end gavn for såvel de interviewede kvinder som for etniske minoritetskvinder i almindelighed. Det nævnes endvidere, at ,bogen inkluderer i god feministisk stil kvindernes egne stemmer [...] men det er stemmer fra kvinder som voldsofre, og deres stemmer er begrænsede. Deres stemmer og vidnesbyrd udlægges som fakta, og det er de på nogle måder også, men som forsker har man ansvar for, at kvindernes historier sættes ind i en større og bredere kontekst“" (ibid.). Problemet synes dog ikke at være mangel på kontekst, men derimod at vi gør brug af de forkerte kontekster, idet bogen kritiseres for at etnificere og kulturalisere volden. De to kritikere ser derimod volden som et ,socialt problem“ - et spørgsmål om ,socialklasse“ - og for de voldsramte kvindelige ægteskabsmigranters vedkommende som et spørgsmål om manglende opholdstilladelse (ibid.). Når de to kritikere hævder, at vi risikerer at skade de voldsramte kvinder, vi har interviewet, siger de samtidig, at kvinderne tilsyneladende ikke er bevidst om, hvad der er i deres egen interesse. Det finder vi påfaldende, idet de interviewede kvinders erklærede motivation for at deltage i projektet typisk har været at skabe øget bevidsthed om vold mod kvinder i etniske minoritetsfamilier og -miljøer.

I en amerikansk antropologisk antologi fra 1992 om kulturelle perspektiver på hustruvold nævner en af redaktørerne, Dorothy A. Counts, i forordet, at antropologer hidtil enten helt har ignoreret „,vold i familien“ eller er gået meget let hen over problemet (Counts 1999). Og hun begynder at forstå, hvorfor det forholder sig sådan. Der er nemlig flere kolleger, der har reageret kraftigt på de diskussioner om vold mod kvinder, som forfatterne til antologien har haft under forarbejdet til bogen. Én reaktion går på, at man ikke bør udnytte og misbruge folks gæstfrihed ved at udstille de dunkle sider af deres kultur. En anden går på, at man ikke skal pådutte andre folk ens egen politiske eller ideologiske agenda, og at man ved at fokusere på vold mod kvinder kan være med til at skabe unødig splittelse mellem kvinder og mænd og dermed ultimativt kan være med til at nedbryde familielivet.

Counts erkender, at der er mange etiske overvejelser i voldsforskningen. Men hun siger samtidig, at det er svært at ignorere praksisser, der resulterer i, at kvinder lider, lemlæstes, dræbes eller begår selvmord. Hun er også inde på, at der er forskellige interesser på spil blandt de folk, man studerer, og at der typisk også er nogen, der opfatter vold mod kvinder som et problem. Det tjener således bestemte interesser, når forskere undlader at beskæftige sig med denne voldsform. 
Beskrivelserne og overvejelserne fra de tidlige 1990'eres USA er på mange måder stadig aktuelle. Som det fremgår af ovennævnte kritik af Andresen og Andreassen (2011) er der fortsat modstand mod at fokusere på kulturens skyggesider, ikke mindst hvis fokus er på etniske andre, og man har et perspektiv, der tillægger kultur en betydning for, hvordan vold praktiseres og forstås. En anmeldelse af vores bog „Rør ved det urørlige“ skrevet af den svenske forsker Pernilla Ouis (2012a) bekræfter, at det er vores fokus på praksis internt i de etniske minoritetsmiljøer, der giver anledning til kritik. I anmeldelsen skelner Ouis mellem ekstern og intern diskrimination, vold og undertrykkelse og siger videre, at den eksterne diskrimination mod etniske minoriteter fra majoritetssamfundets side er velkendt og tryg at skrive om, hvorimod det er kontroversielt at beskrive den interne vold og undertrykkelse i etniske minoritetsmiljøer: En ,sådan negativ opmærksomhed - at 'udpege', som vi ville sige i Sverige - skulle bidrage til at dæmonisere allerede stigmatiserede grupper" (Ouis 2012a:93). Ifølge Ouis ignoreres interne magtstrukturer alt for ofte i svenske intersektionelle analyser af vold, samtidig med at det at give kultur forklaringsværdi for menneskers handlinger bliver klassificeret som udtryk for „kulturracisme“ (op.cit.95).

Vi har undret os over, at nogle forskere, som i øvrigt beskæftiger sig med køn, etnicitet og ikke mindst magt, tilsidesætter et kritisk magtperspektiv, når det gælder vold mod kvinder i etniske minoritetsfamilier, og synes at have større interesse for mediebilledet af mænd med etnisk minoritetsbaggrund end for konkrete kvinder, der udsættes for vold. ${ }^{18}$ Ouis' anmeldelse giver elementer til en forklaring, som kan suppleres med, at mange forskere - i lighed med den brede befolkning i dagens Danmark - opfatter vold som en afmagtshandling, den afmægtiges reaktion, og at de antager, at det altovervejende er personer, der er samfundsmæssigt marginaliseret og har det skidt med sig selv, der udøver vold. Hvis man har fokus på den interne kulturelle dimension af volden, bidrager man til stigmatiseringen. Set i det perspektiv giver det mening at fortie vold mod kvinder i etniske minoritetsfamilier og at lokalisere problemet i majoritetssamfundet ved at gøre det til et spørgsmål om social placering, diskrimination og lovgivning, mens køn, kønsmagt og kultur nedtones eller helt negligeres. ${ }^{19}$

Voldsforskere med en samfundsvidenskabelig baggrund ser derimod typisk vold som den magtfuldes strategiske udspil over for den mindre magtfulde (Gelles 1997; Riches 1986), og koblingen mellem køn, vold, magt og kontrol er også en uomgængelig del af en feministisk og kønskulturel voldsforståelse (Hearn 1998; Harne \& Radford 2010; Kelly 1988; Lundgren 1993; McKie 2005; Merry 2009; Walby 1990). Den kulturelle betydning af vold er også efterhånden i vid udstrækning anerkendt blandt antropologer. Som Sally Engle Merry (2009) skriver, er kønsbaseret vold et globalt fænomen, men det tager forskellige former og findes mere eller mindre hyppigt i forskellige dele af verden (se også Counts, Brown \& 
Campbell 1999). Hvilke handlinger der udlægges som vold, vil også være både omstridt og variere fra sted til sted (Riches 1986; Aijmer \& Abbink 2000), og på samme måde forekommer der typisk lokalt forankrede og kulturelt specifikke forklaringer på volden (Sørensen 1994, 1998, 2001), ligesom volden kan være kulturelt motiveret på forskellig vis. Æresbaseret vold mod kvinder, som typisk er karakteriseret ved, at der er tale om en kollektiv beslutning og et bifaldende publikum (Wikan 2003:21; Sen 2005), adskiller sig således fra den vold, som en etnisk dansk mand udsætter sin kone eller kæreste for. Samtidig kan begge handlinger defineres som vold mod kvinder, og begge kan siges at handle om grænsesætning.

Det følgende afsnit omhandler det herskende voldsperspektiv, som det kommer til udtryk i regeringens handlingsplaner og andre væsentlige udgivelser.

\section{Det herskende voldsperspektiv og tavshed}

Undervejs i vores arbejde med forskningsprojektet har vi bemærket, at der er sket et skred i forståelsen af vold i det officielle Danmark, og at implikationerne af dette skred er en tavsliggørelse af den kobling mellem køn, magt og kontrol, der ligger til grund for en feministisk voldsforståelse. Udviklingen er tilsyneladende ikke enestående for Danmark, idet Liz Kelly, som vi tidligere har nævnt, har beskrevet en tilsvarende situation i England. Udviklingen kommer til udtryk i sprogbrug, termer og perspektiv, som vi skal vise med udgangspunkt i regeringens handlingsplaner for vold. Vores analyse er baseret på en voldsteoretisk læsning.

Regeringen udgav i juni 2010 ,National strategi til bekæmpelse af vold i nære relationer“. Denne nationale strategi fulgte op på regeringens to tidligere handlingsplaner fra henholdsvis 2002 og 2005. Den første, der blev udgivet på Kvindernes internationale kampdag den 8. marts 2002, havde titlen "Regeringens handlingsplan til bekæmpelse af vold mod kvinder". Den anden havde titlen "Handlingsplan til bekæmpelse af mænds vold mod kvinder og børn i familien 2005-2008“. Som det fremgår af titlerne, er der sket et skred fra de to tidligere handlingsplaners fokus på „,vold mod kvinder“ og „,mænds vold mod kvinder og børn“ til et aktuelt fokus på „,vold i nære relationer“. Dette skred i titlerne er ikke tilfældigt, idet den nationale strategi meget konsekvent undgår at tale om vold mod kvinder. I strategien tales der heller ikke om kønsbaseret vold, som ellers er den gængse betegnelse i verdensorganisationer som WHO og FN. I stedet benyttes udtrykket partnervold, som typisk anvendes i sundhedsvidenskabelig voldforskning. I forordet til den aktuelle nationale strategi står følgende:

Ingen kvinder, mænd eller børn skal leve med vold i hverdagen. Vold i nære relationer, også kaldet partnervold, kan aldrig høre hjemme i et samfund, der bygger 
på ligeværd og personlig frihed [...] Vold er et udtryk for manglende respekt for det menneske, der udsættes for volden. Og det er et udtryk for manglende ligestilling (Regeringen 2010:5).

Som det fremgår af citatet, skal hverken kvinder, mænd eller børn leve med vold i hverdagen, og vold er udtryk for manglende ligestilling. Men da der ikke sættes køn på den typiske voldsudøver og det typiske voldsoffer, som ifølge de nationale omfangsundersøgelser er henholdsvis mand og kvinde (HelwegLarsen \& Frederiksen 2007, 2008), kan man umiddelbart få det indtryk, at ,,vold i nære relationer“ rammer tilfældigt og uafhængigt af køn, og bemærkningen om volden som udtryk for manglende ligestilling forbliver af samme grund både kønsneutral og adresseløs. Det nævnes heller ikke eksplicit nogen steder, at den omtalte vold er en straffelovsovertræedelse, eller at den er en krænkelse af kvinders basale menneskerettigheder, hvilket netop betones kraftigt i disse år af organisationer som WHO, FN og Amnesty International (Youngs 2003; Kelly 2005). Samfundsvidenskabelige voldsforskere som fx sociologen Jeff Hearn (1998) har i årevis argumenteret for, at det ikke er ligegyldigt, hvilke termer vi benytter. Hvis det altovervejende er mænd, der udøver vold mod kvinder og børn, skal det ikke skjules bag termer som ,,vold i familien“, ,,vold i hjemmet“, ,,vold i nære relationer“" eller ,partnervold“. Hearn argumenterer derfor for at benytte udtrykket „men's violence to known women“, dvs. mænds vold mod kvinder, de kender. Juristen Isabel Marcus argumenterer til gengæld for, at ,vold i hjemmet“ bedst kan begribes som „terror i hjemmet“, og at det er nødvendigt at droppe eufemismerne for at kunne bryde tavsheden (Marcus 1994:18).

Selv om de tidligere nationale handlingsplaner ikke altid har opereret med et konsistent voldsbegreb, skriver de sig overordnet ind i en anden forståelse af vold end den aktuelle strategi, idet de netop er opmærksomme på betydningen af køn i forhold til, hvem der typisk gør hvad mod hvem. I forordet til handlingsplanen fra 2002 kan man fx læse:

På trods af at vold er strafbart, udsættes kvinder og børn alt for ofte for overgreb, dér hvor de burde føle sig allermest trygge - nemlig i hjemmet. At volden kommer fra en nærtstående person, gør denne type vold ekstra svær at bekæmpe. [...] Ikke alle bruger vold som konfliktløsning. Men det er tydeligt, at det altovervejende er mænd, der er voldelige over for kvinder. Mænds vold mod kvinder kan ses som en manifestation af en grundlæggende ulighed mellem de to køn - som et ligestillingsproblem (Regeringen 2002:5).

Mens voldens primære udøvere og ofre staves ud allerede i forordet i regeringens første handlingsplan fra 2002, tager forordet i den nationale strategi fra 2010 en anden drejning, idet vold beskrives som en naturkraft eller sygdom, der ,rammer“ folk: „Omkring 28.000 kvinder og 9.000 mænd rammes stadig hvert år af 
partnervold“ (Regeringen 2010:5). ${ }^{20}$ Og det nævnes endvidere, at „,den nationale strategi [skal] sætte ind dér, hvor skoen stadig trykker“, idet ,forebyggelse skal have topprioritet i indsatsen“ (ibid.). Efterfølgende, i kapitel 2, nævnes det dog, at der for de 9.000 mænds vedkommende er tale om, at volden oftest er udøvet af en mandlig partner.

I januar 2011 udarbejdede Mandag Morgen i samarbejde med TrygFonden et længere debatoplæg med titlen „Ud af familiens vold. Debat om indsatsen mod vold i nære relationer" “. ${ }^{21}$ Når vi her inddrager netop denne udgivelse, skyldes det, at der er tale om et oplæg med et erklæret ønske om at ville sætte en dagsorden på området. Oplægget dannede grundlag for en konference med deltagelse af folketingsmedlemmer og samtlige aktører på feltet. Det helt gennemgående budskab i oplægget er, at der er brug for nytænkning og øget professionalisering, herunder en målrettet forebyggelse rettet mod de grupper, hvor volden er mest udbredt, og det er påfaldende, hvor tæt det lægger sig op ad regeringens nationale strategi. Nytænkning betyder ifølge oplægget et opgør med den tidligere tendens til kun at tænke kvinder som ofre for vold:

Tilgangen til volden er blevet mere nuanceret. Partnervold opleves ikke længere udelukkende som noget, der rammer kvinder. Derfor taler man ikke længere blot om 'vold mod kvinder', men om 'vold i ncere relationer' eller 'partnervold'. Siden 1990'erne er det blevet en udbredt holdning, at også de voldelige mænd har brug for støtte og behandling. Dette afspejles i de tre nationale strategier, og i dag findes tilbud om behandling til de voldelige mænd i bl.a. København, Roskilde, Odense, Århus og Aalborg. Der findes dog stadig ingen tilbud om støtte eller behandling til voldsramte mænd (Mandag Morgen \& TrygFonden 2011:22).

Argumentet om en mere nuanceret tilgang er ikke holdbart. Det er en kendsgerning, at det netop er feministiske voldsforskere, der tidligt har taget „kontroversielle“ og „følsomme“ emner som fx vold i samkønnede relationer op, herunder vold i lesbiske forhold (se fx Kelly 1991; Barnes 2010). Feministiske voldsforskere har også tidligt taget spørgsmålet om behandling af voldelige mænd op (fx Adams 1990; Hearn 1998; Dobash et al. 2000).

I Mandag Morgen-oplægget omtales den historiske kobling mellem kvindebevægelsen og vold mod kvinder direkte som en mulig hindring for at udvikle og nuancere indsatsen mod vold, idet en kønspolitisk tilgang antages at hæmme en vidensbaseret indsigt i voldens egentlige natur, forekomst og forebyggelse:

Vold i nære relationer skal i højere grad behandles som et socialt problem og i mindre grad som et spørgsmål om ligestilling og kønspolitik. Ligestillingsperspektivet har været centralt $\mathrm{i}$ indsatsen [...] Men den kønspolitiske retorik, der i en vis grad præger feltet, kan også være en hindring for arbejdet med at udvikle og nuancere indsatsen mod vold. Hvis vold i nære relationer betragtes som et særligt 
kønspolitisk problem frem for et socialt problem, bremser det mulighederne for vidensudveksling og læring fra andre social- og sundhedspolitiske områder. Der er en risiko for, at det kønspolitiske perspektiv forhindrer, at feltet udvides med nye parter, der kunne bidrage til at løfte indsatsen - at feltet lukker sig om sig selv. Derudover er der en risiko for, at den kønspolitiske retorik fører til en unuanceret debat, hvor det bliver et spørgsmål om 'mændene mod kvinderne' (Mandag Morgen \& TrygFonden 2011:14).

Fremhævelsen af vold som et socialt problem snarere end et „kønnet“ problem svarer til den position, nogle forskere har indtaget i forhold til vores projekt som beskrevet i forrige afsnit. Det er imidlertid ikke klart, hvad der menes med, at vold skal betragtes som et socialt problem, bortset fra at problemet dermed antages at blive nemmere at administrere og „behandle“. En af de hindringer, der fremhæves i debatoplægget, er interessant nok manglen på en fælles terminologi, der vanskeliggør samarbejdet mellem forskellige instanser:

Der er ikke en terminologi, der er fælles for krisecentre, kommuner og de andre aktører, der er involveret $\mathrm{i}$ indsatsen. Både WHO og CEDAW-konventionen leverer overordnede definitioner på, hvad det kan indebære at være voldsramt. Men begge definitioner er for abstrakte og overordnede til, at de kan danne grundlag for det konkrete arbejde i f.eks. kommuner og på krisecentre. Der er derfor behov for meget mere præcise værktøjer, der kan gruppere voldsofrene [...] Det kunne for eksempel være brugbart at kategorisere voldsofrene i forhold til, hvor traumatiserede de er af volden, og dermed hvilke tilbud om støtte og behandling de har brug for. Beskæftigelsesindsatsens opdeling af arbejdsløse i matchgrupper kunne være et eksempel til inspiration (op.cit.52).

Vi er enige i, at en fælles terminologi og et konsistent voldsbegreb kan virke voldsforebyggende (Danneskiold-Samsøe, Mørck \& Sørensen 2011:39). Det er dog ikke en hvilken som helst fælles terminologi, der efterlyses i oplægget. Selv om vold mod kvinder og kønsbaseret vold er internationalt anerkendte begreber, der trækker på en fælles forståelse, foretrækkes kønsneutrale betegnelser som fx partnervold i oplægget. Endvidere kan forslaget til en kategorisering af voldsofre $i$ forhold til graden af traumatisering nemt tænkes at spænde ben for en helhedsforståelse af fænomenet vold mod kvinder. Vold mod kvinder kan typisk ikke reduceres til at handle om én afgrænset episode, men kan bedst forstås som en proces, der involverer mange voldsformer, og hvorunder kvindens virkelighedsopfattelse forrykkes, og voldens normalisering sætter ind (Lundgren 1990, 1993, 2004). Så hvornår skal målingen eller opdelingen i matchgrupper finde sted?

Der synes også at ske en udhuling af fænomenet vold mod kvinder i forbindelse med den nye tendens til at tale om partnervold mod henholdsvis kvinder og mænd. For hvis partnervold for alvor etableres som en samlebetegnelse for voldserfaringer uanset køn, er det meget tænkeligt, at seksuel vold, der ofte er en in- 
tegreret del af en kvindes samlede voldserfaringer - voldens kontinuum ifølge Liz Kelly (1988) - adskilles fra de øvrige voldserfaringer og kategoriseres som noget andet. Vi er skeptiske over for at reducere fænomenet vold mod kvinder til såkaldt partnervold mod kvinder, der aktuelt optræder som en pendant til partnervold mod mænd..$^{22}$ Det er en konsekvens af det kønsneutrale ligestillingsperspektiv, der forbigår det ubehagelige spørgsmål om magt og koblingen mellem køn og magt.

\section{Konklusion}

Vi har i forskningsprojektet om vold i etniske minoritetsfamilier mødt en samtidig fortielse og tavsliggørelse af den vold, der finder sted. Vi mødte den for det første i kvindernes fortællinger om erfaringer med vold, hvor de berettede om fortielse af volden inden for familien og tavsliggørelse af de kvinder, der bryder loyaliteten over for familien og det etniske minoritetsmiljø ved at fortælle om volden udadtil. Vi mødte den for det andet hos forskere, der var bekymrede for det kombinerede fokus på etniske minoriteter og vold, og som søgte at fortie volden ved at gøre den til et spørgsmål om social klasse og diskrimination snarere end et spørgsmål om kønskultur og magt. Og som for nogles vedkommende forsøgte at tavsliggøre de interviewede kvinder ved at mistænkeliggøre dem eller antage, at de handlede mod deres egne interesser ved at bidrage til projektet. For det tredje erfarede vi en udbredt fortielse af feministiske perspektiver på vold mod kvinder i den danske offentlighed, herunder særligt i handlingsplaner og indsatser, hvor vi ser et skred i retning af at behandle denne voldsform som et socialt problem.

Disse tavsheder kan tilsammen siges at udgøre en „tavshedens sammensværgelse“ (Jackson 2002:48; Krag 2007:26; Sørensen, Mørck og DanneskioldSamsøe, in press) i den forstand, at den vold, som kvinderne i vores undersøgelse er udsat for, forties og gøres tavs fra mange sider. ${ }^{23}$ Det sker i de etniske minoritetsmiljøer, i forskningen og i offentligheden. Et udtryk som sammensværgelse peger ganske vist i retning af intention, hvilket der ikke nødvendigvis er tale om fra alle involverede parters side, idet folk ikke altid kender implikationerne af deres sociale praksis (se Ortner 1984:157). Den samlede konsekvens af de sociale praksisser er imidlertid, at det er svært for kvinderne at finde lydhørhed.

Aktørerne deltager i tavshedens sammensværgelse af forskellige årsager. Mænd og kvinder blandt etniske minoriteter ønsker at opretholde status og ære, ved at familiernes kvinder fremstår ærbare og loyale. Nogle forskere føler et ubehag ved koblingen mellem vold og kultur og fastholder det synspunkt, at vold (mod kvinder) er et socialt problem. De frygter, at fokus på vold mod kvinder med etnisk minoritetsbaggrund vil bidrage til en andetgørelse af etniske minoriteter og 
etniske minoritetsmænd i særdeleshed. Den danske offentlighed kan foretrække ikke at omtale vold mod kvinder og omgå ubehaget ved fx at omtale fænomenet som henholdsvis et ,socialt problem“ og ,partnervold“, fordi vold mod kvinder er foruroligende og kan true gængse antagelser om ligestilling.

En tavshedens sammensværgelse er til gavn for de mennesker, der har adgang til og udøver magt, og ikke for ofrene for vold. Der er væsentligt, at forskere, praktikere og beslutningstagere lytter til ofrene og tager deres perspektiv alvorligt. Det er i det hele taget nødvendigt at lytte til dissidenters stemme i (den gamle) erkendelse af, at (etniske minoritets)samfund ikke er ensartede størrelser med fælles interesser.

\section{Noter}

1. Familien betyder alt. Vold mod kvinder $i$ etniske minoritetsfamilier (Danneskiold-Samsøe, Mørck \& Sørensen 2011) kan fås gratis via TrygFonden, www.trygfonden.dk. Se også Danneskiold-Samsøe, Sørensen og Mørck (2010) og Mørck, Sørensen, Danneskiold-Samsøe og Højberg (2011).

2. Første form for tavshed henviser ikke til nogen kronologi, men til første af tre.

3. Danner og TrygFonden har i øvrigt ikke haft nogen indflydelse på projektets udførelse eller resultater.

4. Danner er her lig med den eller de personer, der har været med til at formulere udbuddet. Ikke alle ansatte og frivillige medarbejdere på Danner er nødvendigvis enige.

5. Undervejs har vi imidlertid fundet ud af, at der er en begrænset kvalitativt funderet forskning i vold mod kvinder i Danmark i det hele taget.

6. Der indgår tre andre større empiridele i undersøgelsen. For det første: interviews med 25 krisecentre organiseret under LOKK. For det andet: interviews med en lang række andre indenlandske aktører inden for området med henblik på at få overblik over feltet og indtryk af de muligheder for støtte, der er til etniske minoritetskvinder. For det tredje har vi på studieture til Berlin, Stockholm og London undersøgt initiativer rettet mod etniske minoritetskvinder samt interviewet nøglepersoner og medarbejdere på krisecentre og lignende institutioner. Vi har også interviewmateriale fra en studietur til Istanbul.

7. Disse lande indgår i den brede definition af Mellemøsten. Betegnelsen Mellemøsten kan i lighed med andre geopolitiske betegnelser kritiseres for at være eurocentrisk, og der findes mange forskellige definitioner, men ingen autoriseret version. Vi gør brug af den brede definition, da der er afgørende fællesstræk i karakteren af den vold, kvinder udsættes for i hele det område, som definitionen omfatter. Se fx http://middleeast.about.com/od/middleeast101/f/me080208.htm

8. „Vold i familien“ og ,vold i hjemmet" er to betegnelser for det samme, og de bruges ofte i flæng. Begge modsvarer den gængse engelske betegnelse ,,domestic violence“. I den feministiske voldsforskning foretrækkes begrebet „,vold mod kvinder“ - „,violence against women“, ofte forkortet til VAW - eller „kønsbaseret vold“ for at pointere denne voldsforms kønnede karakter.

9. Ringsted Krisecenter havde 30-års-jubilæum i 2008. Se http://www.ringsted-krisecenter.dk/ nyheder. Danner fejrede sit 30-års-jubilæum i 2009 med en støttekoncert i Tivolis Koncertsal. 
10. Mens Erin Pizzey oprindelig blev associeret med kvindebevægelsen, er hun efterfølgende blevet kendt for sit syn på vold som en afvigerproblematik: Vold forekommer i dysfunktionelle familier og har ikke noget med køn at gøre.

11. Susanna Alakoski var en af de indbudte oplægsholdere på konferencen „The Silencing of Violence Against Women“i 2011. Se note 12.

12. Konferencen blev afholdt 27. oktober 2011 på Roskilde Universitet. Den var finansieret af Center for Køn, Magt og Mangfoldighed, CKMM, og arrangeret af artiklens forfattere, der præsenterede Familien betyder alt. Vold mod kvinder $i$ etniske minoritetsfamilier ved samme lejlighed.

13. Et eksempel på, at seksualiseret vold er særlig vanskelig at forholde sig til, er et projekt, som den svenske forsker Pernilla Ouis har været forskningsleder for. Projektet, som involverede flere forskere og kvinderettighedsorganisationer i Mellemøsten, blev foretaget som et opdrag fra det svenske Red Barnet. Slutrapporten, der indeholder bidrag udarbejdet af lokale forskere, handler om æresrelateret vold, tidlige ægteskaber og seksuelle overgreb i Libanon, Yemen og de besatte palæstinensiske områder (Ouis \& Myhrman 2007; se også Ouis 2009). Ouis har skrevet det indledende kapitel. Red Barnet insisterede imidlertid på, at 20 sider skulle udgå, da man ikke var enig i hendes opsamling og kontekstualisering af de tre situationsanalyser. Rapporten var accepteret, da Red Barnet fik en ny regionschef for Mellemøsten, som stoppede den. Kritikken gik bl.a. på, at der var for lidt belæg for, at man kunne betegne mellemøstlige samfund som patriarkalske, og at de problemer, som belyses, fx seksualiseret vold, kun forekommer i visse kredse, samt at der blev lagt op til en polarisering, som førte til en dem og os-holdning. Vi har læst de bortcensurerede sider og finder, at Ouis giver et loyalt og nuanceret billede af resultaterne og peger på, hvor der er behov for (mere) viden. Sagens forløb er beskrevet i Güngör \& Dervish 2009. De bortcensurerede sider findes på http://nordicdervish.wordpress.com/2008/ 02/06/meddelande-fran-pernilla-ouis/ Se også: http://www.newsmill.se/print/21784.

14. Beskrivelsen af etniske minoritetsmiljøers opfordring til tavshed tager udgangspunkt $\mathrm{i}$ fortællinger fra kvinder med rødder i Mellemøsten og Sydasien.

15. Erfaringer fra Tyrkiet viser, at feministiske gruppers og kvindeorganisationers italesættelse af og kamp for at få vold mod kvinder på den politiske dagsorden har haft stor gennemslagskraft både $\mathrm{i}$ forhold til forandringer af kvinders voldsopfattelse og lovgivning vedrørende kvinders rettigheder (Danneskiold-Samsøe, Mørck \& Sørensen 2011:363-81).

16. Vi finder det på ingen måde uinteressant at få indblik i mænds perspektiv på vold. I vores projekt var det imidlertid ikke oplagt at tale med kvindernes mænd, da kvinderne havde forladt dem, og mændene i flere tilfælde repræsenterede en alvorlig trussel mod kvinderne; i visse tilfælde en trussel på livet.

17. Se vores udførlige svar på Andresen \& Andreassens kritik på: http://webmagasin.kvinfo.dk/ svar-paa-indlaegget-naar-etnicitet-bliver-det-styrende-parameter.

18. Ouis bekræfter i sin anmeldelse, at det samme er tilfældet i Sverige (Ouis 2012a:94). Ouis påpeger også, at det at problematisere og dekonstruere - og at belyse magtudøvelse - udgør en vigtig bestanddel af den videnskabelige disciplin, men det glemmes tilsyneladende, når det handler om emner som religion og kvindesyn. Hun slår til lyd for vigtigheden af at dekonstruere religions undertrykkende og magtmæssige dimensioner (Ouis 2012b).

19. Intersektionelle tilgange til vold mod kvinder med etnisk minoritetsbaggrund giver undertiden forrang til klasse på bekostning af køn og kultur (se fx Sokoloff \& Dupont 2005).

20. Tallene stammer fra nationale omfangsundersøgelser foretaget af Statens Institut for Folkesundhed af henholdsvis mænds vold mod kvinder (Helweg-Larsen \& Kruse 2004; HelwegLarsen \& Frederiksen 2007) og vold mod mænd (Helweg-Larsen \& Frederiksen 2008). De omtalte 9.000 mænd optræder i den originale undersøgelse som ,godt 8.000 mænd“, og antallet er baseret på et skøn. Samtidig fremgår det, at „partnerens“ køn er uoplyst, og at partneren 
både kan være en egentlig seksuel partner og en, man blot deler bopæl med. „Partnervold mod mænd" dækker overvejende over mænds vold mod mænd (Helweg-Larsen \& Frederiksen 2008: 25).

21. Det fremgår af forordet (s. 7), at Mandag Morgen bærer det fulde ansvar for den foreliggende tekst.

22. En grundig læsning af omfangsrapporterne bekræfter, at mænds vold mod kvinder er et ganske andet fænomen end (partner)vold mod mænd. Et avisindlæg af Lone Nørgaard (2010) har samme pointe. Se også note 17 . Vi ser samtidig en tendens i offentligheden til, at flere - især mænd - kritiserer, hvad de opfatter som kvinders monopol på offerstatus. En af disse mænd kritiserer omfangsrapporterne for at være utroværdige, idet han i sit misogyne indlæg pointerer, at kvinder har en væsentlig andel i volden som voldsudøvere. Se http://www.180grader.dk/Politik/lgnenom-den-voldelige-mand. Tak til Britta Mogensen for denne henvisning.

23. Minoritetsforskeren Helen Krag skriver (Krag 2007:27), at udtrykket tavshedens sammensværgelse (,,conspiracy of silence“) blev indført af psykoanalytiske traumatologer for at beskrive, hvad der sker, når både analytiker og patient undlader at tale om det pinlige og pinsomme, som om det var aftalt på forhånd. Antropologen Michael Jackson nævner i sin omtale af traumatiserede newzealandske veteraner, at ,a psychology of denial had its counterpart in a social conspiracy of silence“" (Jackson 2002:48).

\section{Søgeord: vold, køn, etniske minoriteter, tavshed, Danmark}

\section{Litteratur}

Adams, David

1990 Treatment Models of Men Who Batter: A Profeminist Analysis. I: K. Yllö \& M. Bograd (eds.): Feminist Perspectives on Wife Abuse. Newbury Park: Sage.

Aijmer, Göran \& Jon Abbink (eds.)

2000 Meanings of Violence. A Cross Cultural Perspective. Oxford: Berg.

Alakoski, Susanna (red.)

2007 Lyckliga slut. Sjutton berättelser om vardagsvåldet. Stockholm: Ordfront förlag.

Andresen, Uzma Ahmed \& Rikke Andreassen

2012 Når ,etnicitet“ bliver det styrende parameter. KVINFOs webmagasin. http: //webmagasin.kvinfo.dk.

Balvig, Flemming \& Britta Kyvsgaard

2006 Vold og overgreb mod kvinder. Dansk rapport vedrørende deltagelse i International Violence Against Women Survey (IVAWS). København: Københavns Universitet/ Justitsministeriets Forskningsenhed.

Barnes, Rebecca

2011 Suffering in a Silent Vacuum: Woman-to-woman Partner Abuse as a Challenge to the Lesbian Feminist Vision. Feminism \& Psychology 21(2):233-9.

Christensen, Else

1984 Vold ties ikke ihjel: En bog om vold mod kvinder i parforhold. København: Nyt Nordisk Forlag. 
Counts, Dorothy Ayers

1999 [1992] Preface. I: D.A. Counts, J.K. Brown \& J.C. Campbell (eds.): To Have and to Hit. Cultural Perspectives on Wife Beating. Urbana \& Chicago: University of Illinois Press.

Counts, Dorothy Ayers, Judith K. Brown \& Jacquelyn C. Campbell (eds.)

1999 [1992] To Have and to Hit. Cultural Perspectives on Wife Beating. Urbana \& Chicago: University of Illinois Press.

Danneskiold-Samsøe, Sofie, Yvonne Mørck \& Bo Wagner Sørensen

2011 Familien betyder alt. Vold mod kvinder i etniske minoritetsfamilier. Frederiksberg: Frydenlund.

2010 Den usynlige vold i etniske minoritetsfamilier. Magasinet Humaniora 2:24-7.

Güngör, Emre \& Nima Dervish

2009 Varför mördar man sin dotter? Stockholm: Norstedts.

Dobash, Rebecca Emerson \& Russell P. Dobash

1992 Women, Violence and Social Change. London \& New York: Routledge.

1998 Violent Men and Violent Contexts. I: R.E. Dobash \& R.P. Dobash (eds.): Rethinking Violence against Women. London: Sage.

Dobash, Rebecca Emerson, Russell P. Dobash, Kate Cavanagh \& Ruth Lewis

$2000 \quad$ Changing Violent Men. Thousand Oaks: Sage.

Gal, Susan

1991 Between Speech and Silence. The Problematics of Research on Language and Gender. I: M. di Leonardo (ed.): Gender at the Crossroads of Knowledge: Feminist Anthropology in the Postmodern Era. Berkeley \& Los Angeles: University of California Press.

Gelles, Richard J.

1997 Intimate Violence in Families. Thousand Oaks: Sage.

Harne, Lynne \& Jill Radford

2010 [2008] Tackling Domestic Violence. Theories, Policies and Practice. Maidenhead, Berkshire: McGraw Hill, Open University Press,

Haugaard, Ilse M.

2011 Fanden og hans pumpestok. Et mysterium. København: Gyldendal.

Hearn, Jeff

1998 The Violences of Men. London: Sage.

Helweg-Larsen, Karin \& Marie Kruse

2004 Mænds vold mod kvinder. Omfang, karakter og indsats mod vold. København: Minister for Ligestilling, Det Nationale Voldsobservatorium i Kvinderådet \& Statens Institut for Folkesundhed.

2007 Mænds vold mod kvinder. Omfang, karakter og indsats mod vold - 2007. København: Minister for Ligestilling \& Statens Institut for Folkesundhed.

Helweg-Larsen, Karin \& Marie Louise Frederiksen

2008 Vold mod mænd i Danmark. Omfang og karakter - 2008. København: Minister for Ligestilling \& Statens Institut for Folkesundhed, Syddansk Universitet.

Jackson, Michael

2002 The Politics of Storytelling. Violence, Transgression, and Intersubjectivity. Copenhagen: Museum Tusculanum Press. 
Kelly, Liz

1988

1991/2010 Unspeakable Acts. I: D. Cameron \& J. Scanlon (eds.): The Trouble \& Strife Reader. London \& New York: Bloomsbury Academic.

2005 Inside Outsiders: Mainstreaming Violence against Women into Human Rights Discourse and Practice. International Feminist Journal of Politics 7(4):471-95.

Kelly, Liz, Sheila Burton \& Linda Regan

1996 Beyond Victim or Survivor: Sexual Violence, Identity and Feminist Theory and Practice. I: L. Adkins \& V. Merchant (eds.): Sexualizing the Social. Power and the Organization of Sexuality. London: Macmillan Press.

Krag, Helen

2007 Mangfoldighed, magt og minoriteter. Introduktion til minoritetsforskningens teorier. Frederiksberg: Forlaget Samfundslitteratur.

LOKK

2003

Når drømme og håb forvandles til mareridt. Danske mænds vold mod udenlandske kvinder og børn. LOKK, København.

Lundgren, Eva

1990 Gud og hver mann. Seksualisert vold som kulturell arena for å skape kjønn. Oslo: Cappelen.

1993 Det får da være grenser for kjønn. Voldelig empiri og feministisk teori. Oslo: Universitetsforlaget.

2004 Våldets normaliseringsprocess. Stockholm: ROKS.

Mandag Morgen \& TrygFonden

2011 Ud af familiens vold. Debat om indsatsen mod vold i nære relationer. København \& Lyngby: Mandag Morgen \& TrygFonden.

Marcus, Isabel

1994 Reframing "Domestic Violence": Terrorism in the Home. I: M.A. Fineman \& R. Mykitiuk (eds.): The Public Nature of Private Violence. The Discovery of Domestic Abuse. New York \& London: Routledge.

McKie, Linda

2005 Families, Violence and Social Change. Maidenhead: Open University Press.

Merry, Sally Engle

2009 Gender Violence: A Cultural Perspective. Malden, MA: Wiley-Blackwell.

Mørck, Yvonne, Bo Wagner Sørensen, Sofie Danneskiold-Samsøe \& Henriette Højberg 2011 The Thin Line Between Protection, Care and Control. I: R.K. Thiara, S.A. Condon $\&$ M. Schröttle (eds.): Violence against Women and Ethnicity: Commonalities and Differences across Europe. Opladen: Barbara Budrich Publishers.

Nielsen, Steen Baagøe \& Thomas Gitz-Johansen

2006 Mænd i migrationsægteskaber. Fortællinger om hverdag og vold i danske mænds samliv med udenlandske kvinder. Roskilde \& København: Institut for Uddannelsesforskning, Roskilde Universitetscenter \& Ministeriet for ligestilling.

Nørgaard, Lone

2010 Vold mod mænd. Sammenligningen holder ikke. Kristeligt Dagblad 8. december.

Ortner, Sherry B.

1984 Theory in Anthropology since the Sixties. Comparative Studies in Society and History 26:126-66. 
Ouis, Pernilla

2009 Hounorable Traditions? Honour Violence, Early Marriage and Sexual Abuse of Teenage Girls in Lebanon, the Occupied Palestinian Territories and Yemen. International Journal of Children's Rights 3(17):445-74.

2012a Rør ved det urørlige. Social Kritik 129:93-6.

2012b Dekonstruera mera! Sans-magasin. http://www.fritankesmedja.se/dekonstrueramera.

Ouis, Pernilla \& Tove Myhrman (eds.)

2007 Gender-Based Sexual Violence against Teenage Girls in the Middle East: A Comparative Situation Analysis of Honour Violence, Early Marriages and Sexual Abuse in Lebanon, the Occupied Palestinian Territories and Yemen. Beirut: Save the Children, Sweden.

Pizzey, Erin

1974 Scream Quietly or the Neighbours Will Hear. Harmondsworth, Middlesex: Penguin.

Regeringen

2002

Regeringens handlingsplan til bekæmpelse af vold mod kvinder. København.

2005 Handlingsplan til bekæmpelse af mænds vold mod kvinder og børn i familien 2005-2008. København.

2010 National strategi til bekæmpelse af vold i nære relationer. København.

Remar, Dorte

2011 Nu kan jeg lide mig selv igen. Kristeligt Dagblad 4. marts.

Riches, David

1986 The Phenomenon of Violence. I: D. Riches (ed.): The Anthropology of Violence. Oxford: Blackwell.

Sen, Purna

2005

"Crimes of Honour", Value and Meaning. I: L. Welchman \& S. Hossain (eds.): "Honour". Crimes, Paradigms, and Violence against Women. London \& New York: Zed Books.

Sokoloff, Natalie J. \& Ida Dupont

2005 Domestic Violence at the Intersections of Race, Class, and Gender. Violence Against Women 11(1):38-64.

Sørensen, Bo Wagner

1994 Magt eller afmagt? Køn, følelser og vold i Grønland. København: Akademisk

Forlag.

1998 Explanations for Wife Beating in Greenland. I: R.C.A. Klein (ed.):

Multidisciplinary Perspectives on Family Violence. London: Routledge.

2001 "Men in Transition": The Representation of Men's Violence Against Women in Greenland. Violence Against Women 7(7):826-47.

Sørensen, Bo Wagner, Yvonne Mørck \& Sofie Danneskiold-Samsøe

(in press) A Conspiracy of Silence: Violence Against Ethnic Minority Women in Denmark I: B. Wijma (ed.): Violences and Silences: Shaming, Blaming - and Intervening. Linköping: Linköping University.

Timmerman, Christiane

2006 Gender Dynamics in the Context of Turkish Marriage Migration: The Case of Belgium. Turkish Studies 7(1):125-43. 
Walby, Sylvia

1990 Theorizing Patriarchy. Oxford: Basil Blackwell.

Weeks, Jeffrey

1999 The Sexual Citizen. I: M. Featherstone (ed.): Love \& Eroticism. London: Sage.

Wikan, Unni

2003 Ære og drab. Fadime - en sag til eftertanke. København: Høst \& Søn.

Youngs, Gillian

2003 Private Pain/Public Peace: Women's Rights as Human Rights and Amnesty International's Report on Violence against Women. Signs 28(4):1209-29. 